\title{
Nautanki: Evolution, Issues and Challenges
}

\author{
Siddhartha Singh \\ Associate Professor, Department of English, Sri JNMPG College, Lucknow, India. Email: \\ siddhartha.singh8@gmail.com
}

\begin{abstract}
A major form of folk theatre, Nautanki, still holds an important place in the collective consciousness of the rural mass of the north India. The storyline of this musical folk theatre, exceptional in preserving the written texts, is derived from multiple sources ranging from mythology, history, romances, and folklores to contemporary icons. With its emphasis on music, both vocal and instrumental, accompanied by its most important companion Nakkara or Nagara, the highly intensified operative theatre can hold the nerves of thousands of people for the whole night. Due to the pressure of Bollywood and new sources of entertainment, Nautanki started losing its distinctive character, yet its survival has kept the hope alive. The present paper will not only introduce the form in detail, but will also shed light on some of the important issues and challenges in Nautanki today.
\end{abstract}

Keywords: Nakkara, Sangit, Swang, Bhagat, Music, folk, Virangana, Patriarchy, Indian Feminism.

There was a time when the voice of Nakkara (a single-faced kettle drum), announcing performance of Nautanki, a musical drama, could send a big mass in the Hindi-speaking North Indian villages into a little frenzy. As a chief source of entertainment this folk-theatre of the region had the magical charm to spell bound the audience for the whole night. Though the Indian theatre has its religious roots, ${ }^{1}$ but the popularity of Nautanki, like other folk forms of India, rests on its secular appeal, day to day concerns of common people, and its audacious concern with entertainment to provide pretext for fun. In the Indian context, the idea or the word folk $^{2}$, has wide connotations- ranging from natural to native to traditional to rural and in some cases "from the heart". Here we are away from the privileged moment of individualization in the history of ideas, knowledge, literature and philosophy. There has been an intense association with the sentiments of common people and therefore the form has survived the onslaughts of modern age though not without certain constriction and unhappy mutilations. This traditional folk form, "originally called Sangit ("music") or 'Swang: major musical Hindi-theatre form of north India, encompassing Uttar Pradesh, Bihar, Madhya Pradesh, Haryana, Himanchal Pradesh, and partly, Punjab and Rajasthan” (Jain, 2004, p. 312), has held sway over entire rural population of North India for over four to six centuries. The familiarity with stories, dialogues and songs of the play, be it Sultana Daku, Amar Singh Rathod, Harishchandar, Alha-Udal, Nautanki Shahzadi, Laila-Majnun, Shirin-Farhad, Bahadur Ladki, Ram Kevat Samvad, or Puranmal ka Kissa etc., never diminished the interest and fun in it as it was the performativity (how the whole world of the play had been brought into being with its action) of art, witty improvisations, lusty singing and spirited dance (sometimes lewd) that held the nerves of the audience. The familiarity never deterred the audience to sit through the performance from early evening to dawn, engrossed in the rhythm of the powerful Nakkara and the deep throated voice of the singers.

(c) AesthetixMS 2020. This Open Access article is published under a Creative Commons Attribution Non-Commercial 4.0 International License (http://creativecommons.org/licenses/by-nc/4.o/), which permits non-commercial re-use, distribution, and reproduction in any medium, provided the original work is properly cited. For citation use the DOI. For commercial re-use, please contact editor@rupkatha.com. 
It is very difficult to trace the history of any moving folk-theatre. As for as origin of Nautanki is considered, there is no definite point of beginning, yet we find the mention of related forms in Ain-I-Akbari, a fifteenth century treatise, where there is a reference of a group of mendicants. Under the influence of Bhakti movement, they used to preach during the night imitating and enacting the religious leaders of the time. Later these men formed their own troupe and travelled all over North India. Nautanki, as a less religious form became full of dancing; pulsating drumbeats and full-throated singing. It emerged as a big source of entertainment in North India. Cultural transmission and intermixing had been keys to its success. I agree with Hansen's observation that "Nautanki has contributed to the formation of North culture. Together with other cultural practices, it has generated a set of meanings that render the experience of its society comprehensible to its own members". (1991, p. 3) Nautanki has gone under tremendous change in the modern era. The most important aspect of this folk form is that "Unlike many other traditional theatres, Nautanki preserves complete written texts, a kind of libretto, for all characters including the Ranga, the director-narrator ...". (Jain, 2004 312) A history, though controversial, of its development is found in the main centers of its modern origin; Hathras and Kanpur. It is believed that Hathras style developed earlier and Kanpur later. Both the schools follow the same theatrical structure, but their presentations differ, especially in singing style. The full throated robust singing style of the Hathras School is replaced by soft singing and dialogues in Kanpur school. As the structure and the way of living of these two cities are different so the basic styles. While Hathrasi School emphasizes more on singing, and is operatic in form, Kanpuri School centers itself more on prose filled dialogues mixed with singing. (Sharma, 2006 44). Swann (2007) elaborates the basic differences

The Hathras and Kanpur styles of Nautanki are distinguished by both artistic and organizational differences. In Hathras the songs are generally higher pitched and the singer holds on to notes, elaborating and ornamenting them. In Kanpur style the music is subordinate to the dramatic requirement of the play. The manner of singing is less demanding: The pitch is generally lower, and there is little ornamentation in the singing. The Hathras style requires a great deal more genuine musical skill. Like opera anywhere, Hathras Nautanki is hard to understand because of the ornamental style of singing, but Kanpur style songs can be followed easily, a consequence of Srikrishna Pahalwan's background in reciting poetry. (264-65)

There are different opinions about the name Nautanki itself. Some of the scholars opine that it is derived from Sanskrit word (and of course Sanskrit tradition) Nātak. However the most popular myth of the origin of the word Nautanki is the story of the princess Nautanki of Multan (Shahazadi Nautanki). Made of two words Nau means nine and tank, a measure of silver currency equivalent to approximately four grams, thus this Shahazadi of peerless beauty was believed to weigh only thirty six grams. The description of her beauty runs like this

She dwelt cloistered in an impenetrable palace, surrounded by dense groves and watched overnight and day. Distant and inaccessible though she was, her name had reached all corners of the country. Here was a damsel whose delicacy put even the fairies to shame. The radiant glow of her body made the moon's luster pale. Her eyes were like a doe's; she had the voice of a cuckoo. When she laughed jasmine blossoms fell. In the prime of her youth, she maddened men with her lotus-like breasts and three folds at her waist. When she set foot outside, she was as if borne aloft on the gusts of wind ... Such was her supreme ethereality that her weight could be measured only against a portion of flowers. (Hansen, 1991, p. 10) 
Once a handsome and adventurous Punjabi prince named Phul Singh, taunted by his elder brother, Bhoop Singh's, wife on asking to serve food quickly (that he was behaving as if he were a husband of Shahzadi Nautanki) feels so insulted and hurt that he leaves the home and in fashion of a Knight of the middle ages takes a vow that he will return only after marrying the Princess. Accompanied by his faithful friend Yashwant Singh, he reaches Multan and he meets the flower-women of the palace, who carries a garland of fresh flowers to princess every day. He begs her to allow her to live in her hut. Phul Singh, an expert in the art of floral decoration offers her to prepare a unique garland for the Princess, if the flower-women will cook for him. She agrees. Phul Singh weaves so impressive a garland that the princess suspects that it is not made by her flower-woman. Upon her enquiry, she is told that it has been prepared by the wife of flower-woman's nephew who came to stay with her for a few days. The princess commands her to produce her daughter-in-law. Greatly disturbed she reaches her hut, but Phul Singh assures her that he is a superb disguiser and will go with her in disguise of a woman. Very much like Viola in Shakespeare's Twelfth Night (however role is reversed here, it is a male disguised as female) Phul Singh, disguised as a woman, is presented in the service of the princess. Phul Singh is struck with her beauty and falls in love with her. The princess too feels some attraction and proposes her friendship and insists that (s)he should stay with her in her chamber, which Phul Singh happily accepts. During the intimate talk with her newly found friend, the princess reveals

Listen, most excellent gardener girl,

I am weighed in flowers until now.

No man has proven worthy of me,

So I've remained single, in spite of my budding youth.

Seeing you, my friend, a wave surges in my heart.

Oh sweet, if only one of us could be changed into a man,

We could spend the whole night making merry in bed,

Happily embracing, giving and takin,

Drinking the cup of union. (Hansen, 1991, p. 24)

Phul Singh (very similar to Viola and Rosalind) asks her to close her eyes, meditate on the household gods and invoke their blessings to turn one of them into a man. She agrees to act like that and on opening the eyes she finds that her friend has turned into a handsome man and they spend night together. When the next morning she is weighed in flower and the scale is tipped off, the matter of her union with a man is disclosed. The infuriated King orders to arrest and kill Phul Singh. It's a very symbolic scene revealing the patriarchal motifs where too much importance is attached to the chastity of women. Princes who is defined as only 36 grams and pure in her virginal state, has now gained weight due to her sexual contact with Phul Singh, which carries the cultural signification (exclusively for female gender) of being defiled, tainted and corrupt. Foucault would call it "repressive hypothesis" (1984); the hypothesis that the loss of chastity weighs her down. At this point of analysis all the western feminists would criticize how in this case power is controlling sex to retain its status, but the story moves further and even challenges and reverses the role of gender; hence presents an Indian alternative-cum-compliment-cum-supplement to the project of western feminist movements to explore feminism in Indian terms.

At the gallows two executioners, one wicked and one merciful, debate over Phul Singh's fate. Suddenly Nautanki storms the execution ground, dressed as a man and armed with 
sword and dagger. Phul Singh is content with this last glimpse of her, and says goodbye to the world as the noose is placed about his neck. But Nautanki pulls out a cup of poison and prepares to commit suicide, vowing to die as Shirin died for Farhad and Laila for Majnun. As the executioner advance to pull the cord, she rushes with her dagger and drives them off. She then turns her sword on her father, demanding, he pardon her lover at once. The King consents to the marriage and the two are wed on the spot. (Hansen, 1991, p. 25)

So suddenly the worst turns to be the best. Phul Singh returns home with his newly wed bride, a woman warrior, as a victorious Knight. Though there are several variations of this story and even names are changed according to locality, the story remains the same.

This concept of women warrior or Virangna is an alien concept in the western model of feminism. This had been part of Indian culture since the time immemorial. Kaikeyi helped Dashrath in the battlefield and saved his life. There are several mythical and more historical evidences of such characters. Indian literature too is full of such character and the best example is the character of Chandrakanta of Chandrakanta (Santati) by Devkinandan Khatri. ${ }^{3}$ When the west was writing about tragic heroines like Tess and Anna, Devki Babu was solidifying the concept of Viranganas, but only a few critics adopt and analyze this concept. Kathryn Hansen's paper, "The Virangana in North Indian History: Myth and popular Culture" (1988), is an exception. She makes an important comment on the act of princess Nautanki

She braves social censure, daring to leave the seclusion of her palace and appear in public, thus demonstrating the great measure of her love. She also challenges the chief representative of society's moral order, the king ... by pleading for permission to marry and even threatening his life. To carry out her brave resolve, she transforms herself into a warrior figure, attired as a soldier on a horse, carrying weapons in these cases then, the virangana shares some of the characteristic of the historical queens, including the male costume, position on horseback, and protective use of sword and dagger. (Hansen, 1988, p. 30)

In this article she rightly argues for a third model after Sita/Savitri and the Shakti goddesses. This mythical story is always mentioned by composer and the impression of this episode had been so strong in the minds of the connoisseurs of Nautanki (despite the fact that there is no such history anywhere) that this story is now not just a permanent part of folk tradition, but the princess Nautanki also became so famous that it came to signify the theatre genre itself. The first published form of the story is Khushi Ram's Sangit Rani Nautanki Ka (The Musical Drama of Queen Nautanki 1882). Later compositions and repeated performances popularized the form and moved out from the Punjab region and Haryana into Uttar Pradesh and Bihar.

There are at least three forms of folk theatres which can be said to beget Nautanki: Bhagat, Svang (described briefly in the works of Kabir, (Swann, 2007, p. 251)) and Sangit. An earlier reference of Svang is also found in the folk songs of Dom caste. (Swann, 2007, p. 251). As far as structure, form and style are concerned, Nautanki seems to be closely associated with, and a later development and improvisation of Bhagat, the style which is mentioned in Ain-I-Akbari. However there are some basic differences between these two forms. While the first is deeply associated with Hindu religious and spiritual themes, the later includes stories of romance, valor, adventures and sometimes love scenes breaking the barrier of decency. Its professionalism lays basis for it being secular as the performances have been for mixed audiences of different religions. What is important to note here is that in most of the traditional stories the moral fiber of the Hindu tradition is maintained. Indeed, with some exceptions, the themes, lyrics and the stage itself had been same in most of the cases. Each Guru of Bhagat has his own Akhara (or pit) and followers, (while Nautanki had slightly different organizational structure of troupes). Nautanki is a vocation for all its 
performers and being nonsectarian concentrates on entertainment. The pits of Bhagat would receive donations and contributions from the patrons and rich people.

Though there had been friendly competition between various pits, no one was allowed to join another Akhara. (Same system as those of the Hatras style of Svang and even the instrument used were same). This had been a hard and fast rule to be followed by every follower in Bhagat tradition. The guru is the writer, director, and composer. After lighting the sacred lamp to raise lord Ganesha (in which the actor Ganesh himself dances on the stage) the actual performance starts. Needless to say that this tradition to invoke, either Lord Ganesha, Goddess Saraswati, Lord Shiva or any other God, of Sanskrit classical theatre is followed by these folk forms. While Bhagat retains religious fervor with several rituals accompanying its performance, these rituals are a just a formality in Nautanki, and immediately after the ritual starts the female dance (one can compare it with the concept of item dance) to entertain the audience. The actual story begins after that.

After the mutiny of 1857 , the colonials realized the impact of Bhagat's performers on the masses, and proceeded to exploit these practitioners' art for furthering their own cause. To divert the attention of the masses from revolutionary sentiments the gurus were forced to write vulgar, erotic and titillating Bhagats. It is said that Bhagwati Prasad of Kalangi troupe was offered ten thousand rupees to write a love-story named Sabzpari. Bhagat was gradually getting commercialized. Now it is almost extinct and Nautanki has completely replaced it.

Nautanki is exclusively a musical play (obviously dominated by lyrics) with strong storyline (both poetic and prosaic), prose dialogues (minor in proportion to sung passages) and dances. Music with strong meter constitute the most important nonverbal system of communication. The sung repertoire of Nautanki was rich in melodic types and was mostly based on classical Ragas, but in the later developments we find significant digression from classical form to folk form of singing style. The music pattern is determinant of the performance and through its cyclic meter and rhythmic cadences, a connoisseur of Nautanki, without watching the performance, can tell whether it is the story of Alha or Laila Majnu or Ras Lila. The musical and metrical structure are the only unifying elements for a diverse body of narratives so different in form and structure. The music in Nautanki is characterized by strong rhythm, open-throated singing, forceful vocal style of high uppermost notes, burst of emotions, rapid ornamental turns, melismatic (in which a single syllable of text is sung and carried through many notes as opposed to syllabic, in which each syllable of text is matched to a single note) ascents and descents, and adorned vocal lines. In fact as Hansen opines in her interview that "Nautanki as a genre can be identified by its distinctive meters". (Hansen, 2013, p. 77) Another distinctive feature is the use of musical instruments. Nakkara is the main instrument (because of its strong resonance it carries for miles through the night air) which is not only used during the performance to maintain the rhythm and fill the interval after each stanza, but is also used to announce about the performances of Nautanki. The Nakkara player dominates the music, and a performance without him would be unthinkable. (Swann, 2007, p. 254) The vocal quality of Sarangi, the appropriateness of Dholak for sharp rhythm and loud voice, Shahnai and flute for themes of romance and flirtatious games, and Harmonium are other accompanying instruments. First Doha, which is sung freely, second Choubola, which forms the main stanza, and third Chattii, which is sung at a great speed, are some of the most important meters (Kada and Daur are also useful) normally used in recitation. After one or two lines the nakkara is played for the same duration. The tempo of narration is slow and even though the audience is aware of the story, the suspense and interest in performance is maintained. The higher range of singers ensure the popularity of a troupe. The style of singing is very much like Opera. It always elaborates ornamentation of a vocal melody. Some meters are in the name of the protagonists. Alha, from 
Bundelkhand region and Dhola from Rajasthan are such performances. Based on the bravery of two Rajput brothers of twelfth century Mahoba, Alha and Udal (written by Jagnik in Alha Khand) the performance employs alha meter and sung by Alha singers. The meter Dhola, an example of ballad form, is also the name of the hero of the medieval Rajasthani epic Dhola Maru. Nautanki also employs other folk genres like dadra, thumri, savan, along with traditional Urdu prosody like, ghazal, qavvali, sher and so on. As for as language is concerned it is mixture of north Indian Hindi, Punjabi and Hariyanwi. In Kanpur style Urdu words are more in use, while in Hathras style Khadiboli is more important.

There are thousands of Nautanki plays. Most of them are produced by two important centers Hathras-Mathura and Kanpur-Lucknow. The Nautankis of Braj or Hatras School or style are mainly written by Inderman and his disciple Nathram Gaud, while the most important writer of Kanpur style was Srikrishna Pahalwan. They had also been good singers and as a result the dialogues in their plays are often lyrical.

Nautanki has adopted stories and themes from multiple sources. Relying on oral and written narratives from the Indian soil as well as from Arabic and Persian tales of romance and martial, these stories are dominated either by Vir or Śringar Rasa. Undoubtedly India remains one of the world's richest source of folk tales derived from epics, the various Ramayanas, the Mahabharata, to Jatak tales of Buddhism to Panchatantra, Hitopdesh and Kathasaritsagar to actual historical legendary figures. Nautanki too includes various legends and tales from The Ramayana, The Mahabharata, Puranas, folk stories, popular love stories like Laila-Majnu, Shirin-Farhad, historical themes (especially Rajput legend) like Amar Singh Rathod, and true stories of bravery such as Sultana Daku and Andhi Dulhan etc. Social problems are also reflected in some of the Nautankis like Bhikharin, Bahu Begaum, Beti Ka Sauda and Bharat Durdasha (all written by Srikrishna Pahalwan) etc. An important $19^{\text {th }}$ century Nautanki was Indrasabha (the Court of Indra) by Agha Amanat, the famous Urdu poet of Lucknow. He used traditional melodies coupled with niceties and subtleties of Urdu Shayari, folk tunes and seasonal dances along with dramatic lyrics. This musical play went into many editions with modifications and improvisations in its characters, situations, and melodies. Its popularity inspired other Nautanki writers to write similar stories of fairies, devils, gods, princes, wizards and dancers. Model stories of integrity and uprightness like Puran Mal and patriotic stories with political messages during the freedom struggle had also been adopted. The writings of Srikrishna Pahalwan are the best examples:

During the Gandhi-led non-cooperation movement of 1920-1921, one of his plays entitled Non-Cooperative Pickels (Asahyog Chatni) was widely distributed in North India at a few cents per copy. He also wrote and staged in Kanpur his play dealing with the British massacre of Indian nationals at Jalianwala Bagh. This he entitled The Senseless Massacre (Khune Nahak). The impact of his writing and productions was such that the British placed him under strict surveillance; refusing to be intimidated, he staged the play again in Najivabad. Finally, by order of the district official, he was forced to leave that area. (Swann, 2007, p. 263)

As for as the structure of these plays are concerned, they never followed the concept of three unities, except the unity of action. These plays are loosely structured and the imagination of the writers crossed the barriers of time, space and environment. Sometimes a female character from epics could dance like a courtesan. The dialogues may be filled with exaggeration and melodrama. Yet all these taken together would create a new dramatic consciousness. The more it was influenced by Parsi theatre the more urban vulgarity and obscenity started creeping into the performances. The Kanpur troupe became a haunting ground of prostitutes. Use of obscene and vulgar songs 
based on film-tunes started increasing. Hathras troupes were restrained their tendencies towards vulgarity, therefore they were less vulgarized than Kanpur style. The director of Braj Lok Manch of Hathras, Radheshyam made significant contribution to direction by maintaining the purity of the tradition of Nautanki. Swann (2007) aptly summarizes that "Nautanki is narrative in structure, operative in style, and secular in spirit." (249)

As for as performers are concerned men impersonated women till women joins Nautanki around 1920s. The contribution of female performers like Gulab Devi and Malika Begum had been historical and a separate article can be written on the tradition of female performance. Some of the researchers have attempted, but still there are much scope of investigation. ${ }^{4}$

Post-independence India witnessed new grounds in folk theatre. Plays are written and produced in Nautanki style. One can mention Bakri written by Sarveshwar Dayal saxena and Ek Satya Harishchandra of Lakshmi Narayan Lal. Fanishwar Nath 'Renu' has beautifully woven entire atmosphere of Nautanki in his famous story "Mare Gaye Gulfam", which is widely known because of its film version Teesri Kasam (The Third Vow). The film won the National Film Award for Best Feature film at the 14 tNational Film Awards. Indeed Indian cinema is deeply indebted to Nautanki, be it plots, styles of song, dance, lyrics, etc, but domination of cinema has sent this folk form into oblivion. By the last decade of the $20^{\text {th }}$ century, most Nautanki company had collapsed. The Sangeet Natak Akedemi award to Shrikrishna Pahalwan in 1968 and Padma Shri to Gulab Bai in 1990 could not provide enough support to the genre. Though the induction of sensuous and lusty dances on popular Bollywood songs, the efforts of few troupes as The Great Gulab Theatre Company, Krishna Kala Kendra, Brij Lok Madhuri etc. and efforts to synthesize the traditional and the modern by Badal Sircar, Habib Tanvir, Bansi Kaul, M. K. Raina, Shanta Gandhi etc. have anyhow saved this genre, the revival of this form as an important source of entertainment seems to be a chimera in the age of $4 \mathrm{G}$ and $5 \mathrm{G}$. Though this genre "is finding new audiences- in metropolitan cities as a rich folk form with connections to Bollywood, in countries with a large Indian Diaspora, and also in academic institutions as a subject of research into popular culture. Mainstream theatre, notably Atul Kumar's blockbuster 'Piya beharoopiya' borrows heavily from the folk form. But in its home ground, the towns and mofussil areas and badlands of Uttar Pradesh and Bihar, it is often sadly reduced to its filmi caricature, the 'Bidi Jalayile' clones." (Nair, 2016)

Missing contemporaneity is another issue as Devendra Sharma, son of famous Nautanki performer Pundit Ram Dayal Sharma (himself a Nautanki performer and perhaps the only performer who earned a $\mathrm{Ph}$. D. on this form) makes an important observation that "Only a handful of folks chose indigenous performance forms to make contemporary statements. On the other hand, the upper and upper-middle classes adopted a kind of superficial missionary toward saving the indigenous folk forms". (2006, p. 47-48) These are genuine concerns. Texts in new contexts are needed to aspire contemporary audience. Nautanki should give voice to the sensibilities which are now rapidly changing in a cyber world of virtual reality. Nautanki has to face another challenge to retain originality of its form. Performers will have to strike a fine balance between their tradition and the new idioms of the postmodern age. Even the narratives from the remote past have to be performed in a new manner. There is no need to seek western approval; instead our cultural ethos, ethnicity, ecological and family value systems are to be investigated and discussed to fetch attention of the new generation. Such folk forms, as Gargi Balwant opines are the only arts that have "exciting forms, evolved by actual battling with the needs of the audience and actors". (1991 ix) Only this "battling" can save these folk forms and as academicians and teachers it's our responsibility to develop theoretical and practical approaches of our native inheritance among our students. 


\section{Notes:}

1. The Nātya-śästra of Bharata is probably one of the earliest and certainly one of the best and most comprehensive encyclopedic treatises on Indian Dramaturgy. Nätya-śástra, the sole authority on Indian Dramaturgy, was described as the fifth Veda. "Nātya was created by Brahma" for the people "goaded by greed and avarice, and jealously and anger, [who] took to uncivilized (vulgar) way of life", with an aim to "not only teach" them "but be pleasing to eyes and ear" (Rangacharya, 1996, p. 1). Thus Nātya was created to be accessible to all the varnas including Sūdra, who were prohibited from listening to (learning from) the Vedas. Brahma took words from Rgveda, music from Sāmveda, movements and make-up from Yajurveda, and emotional acting from Ätharvaveda in order to create an additional Veda. However, unlike the four Vedas, it is not confined to realm of wisdom alone; it provides entertainment too. In fact entertainment is given priority as the aim of drama is to attract common people. This is the mythical story of the origin of drama in the form which Bharata gave. Just as Panini standardised classical form of Sanskrit, so Bharata standardised classical form of Drama.

2. It is important to note that the Indian concept of folk theatre differs from the Western concept: "Folk drama exists on a village or small group level. The performers are members of a community and therefore known to the most of the audience. The dramas are given on special occasions only, most commonly a seasonal festival" (Abrams, 1972, p. 354). Thus whereas in the context of the West folk designates village-level social organization, Nautanki, from the beginning had been an organization of professional actors from different places and there is no regular connection to seasonal celebration.

3. It is not merely a coincidence that Devkinandan Khatri chose the title of the first "best-seller" Hindi classic novel Chandrakanta (serialized 1887, published in full 1892) after the name of his female protagonist and the subsequent narrative sequence bears her name Chandrakanta Santati. A daunting incomparable task, that was not possible even for those carrying the 'White man's burden' to choose a title after the name of a female protagonist (and even if female names are chosen, the story turns to be tragic for them). Throughout Chandrakanta (Santati) Khatri creates plethora of such female warriors who are perfect embodiments of valour, beauty, wisdom, chastity and delicacy.

4. Vyomika Sharma Bhardwaj's (2013) dissertation 'Nautanki'- Folk Theatre: A study of Women Performers and Audience in Mathura, Uttar Pradesh makes an effort but falls short of being a good dissertation to conduct study of the female performers.

\section{Works Cited.}

Abrahams, Roger D (1972). "Folk Drama," in Richard M. Dorson (Ed.), Folklore and Folklife: An Introduction, (pp.351-362). University of Chicago Press.

Bhardwaj, Vyomika Sharma (2013). 'Nautanki'- Folk Theatre: A Study of Women Performers and Audience in Mathura, Uttar Pradesh. Dissertation submitted to University of Delhi (Lady Irwin College). https://www.academia.edu/30958727/nautanki_folk_theatre_a_study_of_women_performers_and_audi ences_in_mathura_uttarpradesh $>$ accessed 24/08/2020.

Gargi, Balwant (1991). Folk Theatre of India. Rupa.

Foucault, Michel (1998). The History of Sexuality: 1 (1978) Penguin Books.

Hansen, Kathryn (Apr. 30, 1988). "The Virangana in the North Indian History: Myth and Popular Culture", Economic and Political Weekly. Vol. 23, No. 18, pp. WS25-WS33. http://www.jstor.org/stable/4378431.

(1991) Grounds for Play: The Nautanki Theatre of North India. University of California Press.

(2013) "Communicating Configuration of Knowledge: An Interview with Kathryn Hansen" by Suzanne L. Schulz. Sagar. Vol. XXI, sagarjournal.org. 
9 | Nautanki: Evolution, Issues and Challenges

Jain, Nemichandra (2004). “Nautanki”, in Anand Lal (Ed.), The Oxford Companion to Indian Theatre, (pp. 312313). Oxford University Press.

Nair, Malini. “Not Just Naughty”. https://www.thehindu.com/feature/magazine/not-justnaughty/article14621840

Rangacharya, Adya (1996). The Natyasastra. Munshiram Manoharlal Publishers.

Sharma, Devendra (2006). Performing Nautanki: Popular Community Folk Performance as Sites of Dialogue and Social Change. Ph. D. thesis submitted at Faculty of Communication, Ohio University, <etd.ohiolink.edu>

Swann, Darius L (2007). "Nautanki", Indian Folk Theatre: Traditions of Performance. Editors Farley P. Richmond, Darius L. Swann and Phillip B. Zarrilli. Motilal Banarsidas, 249-274. 